СИСТЕМНИЙ ПІДХІД ЩОДО ПІДГОТОВКИ БАКАЛАВРІВ З КІБЕРБЕЗПЕКИ В УМОВАХ ОСВІТНЬО-ЦИФРОВОГО СЕРЕДОВИЩА

\title{
A SYSTEMATIC APPROACH TO THE PREPARATION OF BACHELORS IN CYBER SECURITY IN THE EDUCATIONAL AND DIGITAL ENVIRONMENT
}

у статті описано системний підхід щодо підготовки бакалаврів з кібербезпеки в умовах освітньо-цифрового середовища. Проаналізовано поняття «системний підхід» та «система». Зазначено, що системний підхід щодо підготовки бакалаврів з кібербезпеки в умовах освітньо-цисррового середовища бере в основу процеси створення і фунниіонування педагогічних систем професійної підготовки в залежності від певних умов. З позицій системного підходу окреслено структурні компоненти педагогічної системи підготовки бакалаврів з кібербезпеки в умовах освітньо-цифрового середовища. До таких компонентів віднесено основні базові характеристики педагогічного процесу підготовки бакалаврів з кібербезпеки в умовах освітньо-цифрового середовища, сукупність та фракт наявності яких відрізняється від інших систем. Виходячи із зазначених умов, визначено, що в педагогічній системі підготовки бакалаврів 3 кібербезпеки в умовах освітньо-цисррового середовища такими структурними компонентами є: мета підготовки бакалаврів з кібербезпеки, навчальна інформація, освітньо-цисррове середовище, способи педагогічної комунікації, зокрема в мережі Інтернет, здобувач вищої освіти (майбутній бакалавр з кібербезпеки) та педагог. Зазначено, що особливість системного підходу щодо підготовки бакалаврів з кібербезпеки в умовах освітньо-цифрового середовища полягає в тому, що він орієнтований на розкриття цілісності об'єкта і забезпечуючих ї механізмів, на виявлення різноманітних типів зв'язків складного об'єкта і зведення їх в єдину теоретичну картину, зокрема в умовах глобальної мережі Інтернет. Охарактеризовано сутність системного підходу щодо підготовки бакалаврів з кібербезпеки, що полягає в комплексному досліджені великих і складних об'єктів (педагогічних та мережевих систем), дослідженні як єдиного цілого з узгодженим фрункціонуванням усіх елементів і частин. Зазначено, що згідно із системним підходом система підготовки інженерів з кібербезпеки - че чілісність, яка становить єдність закономірно розташованих і взаємопов'язаних частин в умовах мережевого навчання. Обгрунтовано, що застосування системного підходу сприяє значному підвищенню ефективності підготовки бакалаврів з кібербезпеки в умовах освітньо-цифррового середовища.
Ключові слова: система, системний підхід, бакалавр з кібербезпеки, освітньо-цисррове середовище.

The statute describes the systemic approach for the training of bachelors in cyber security in the minds of the educational-digital middle school. Analyzed the concept of "systemic pidhid" and "system". It has been assigned that the systemic approach for the training of bachelors from cybersecurity in the minds of the educationaldigital middle school is based on the process of establishing and functioning of pedagogical systems of professional training in the presence of singing minds. The structural components of the pedagogical system and training of bachelors from cybersecurity in the minds of the educational-digital middle school are based on the position of the systemic approach. To such components, the basic basic characteristics of the pedagogical process of training bachelors in cybersecurity in the minds of the educationaldigital medium have been introduced, and the fact of the obviousness of such systems is introduced. It's important that the educational systems for the education of bachelors from cybersecurity, in the minds of the educationaldigital middle school with such structural components: great education (maybutniy bachelor of cybersecurity) that teacher. It has been designated that the peculiarity of the system approach for the training of bachelors in cybersecurity in the minds of the educationaldigital middle of the field is in the fact that it is the reason for the development of the efficiency of the mechanism and for the loss of the folding I have only one theoretical picture, it is growing in the minds of the global internet. The day-today of the systematic approach to the training of bachelors in cybersecurity, as well as to the complex education of great and folding objects (pedagogical and measure systems), to the advanced training of bachelors in cybersecurity, is characterized. It is intended that the system for the training of engineers in cybersecurity is an integral part of the system, which is to establish a single set of regular and interconnected parts in the minds of the meshwork. It has been established that a systematic approach to the development of a significant increase in the effectiveness of training bachelors in cybersecurity in the minds of the educationaldigital middle school has been established.

Key words: system, system pidhid, bachelor of cybersecurity, light-digital middle.
Постановка проблеми в загальному вигляді. У сучасному світі відбувається небачений прогрес знання, що призвів до відкриття і накопичення множини нових фрактів, зведень із різноманітних галузей життя і тим самим поставив людство перед необхідністю їх систематизації. 3 іншого боку, прогрес знання породжує складності його освоєння, виявляє неефективність ряду методів, використовуваних у науці і прак- тиці. Перехід до цисррового світу розширює межі подання та захисту інформації, а отже, виникає потреба в якісній сучасній підготовці бакалаврів 3 кібербезпеки, зокрема в умовах освітньо-цифррового середовища. У контексті зазначеного слід підкреслити той фракт, що виникає потреба в розробленні основних принципів системного підходу щодо підготовки бакалаврів з кібербезпеки в умовах освітньо-цифрового середовища. 
Аналіз останніх досліджень і публікацій. Загально-методологічним питанням щодо методологічних основ системного підходу присвячували роботи В.Л. Ортинський, Г.М. Коджаспирова, В.П. Беспалько, І.І. Костікова. Поняття системи як складника педагогічного процесу підготовки фрахівця висвітлена в роботах Н.А. Доценко, Г.С. Кашиної, Т.А. Жижко й І.І. Руснака. Особливостям професійного навчання присвячували роботи Л.В. Оршанський та В.К. Сидоренко. Але питання щодо особливостей системного підходу щодо підготовки бакалаврів з кібербезпеки в умовах освітньоцифрового середовища досліджено недостатньо.

Мета статті - окреслити основні принципи системного підходу щодо підготовки бакалаврів 3 кібербезпеки в умовах освітньо-цифрового середовища.

Виклад основного матеріалу. Системний підхід, який відноситься до загальнонаукової методології, потребує враховувати кожний об'єкт наукового дослідження. Поняття «системний підхід» починає широко вживатися в 1960-1970 рр., хоча саме прагнення до розгляду об'єкта дослідження як цілісної системи виникло ще в античній фрілософііі та науці (Платон, Аристотель). Ідея системної організації знання, що виникла в античні часи, формується в середні століття й отримує найбільший розвиток у німецькій класичній фрілософії (Кант, Шеллінг). Класичний зразок системного дослідження - «Капітал» К. Маркса. Втілені в ньому принципи вивчення органічного цілого (сходження від абстрактного до конкретного, єдність аналізу і синтезу, логічного та історичного, виявлення в об'єкті різноякісних зв'язків та їх взаємодії, синтез структурно-срункціональних і генетичних уявлень про об'єкт тощо) з'явилися найважливішим компонентом діалектико-матеріалістичної методології наукового пізнання. Теорія еволюції Ч. Дарвіна служить яскравим зразком застосування системного підходу в біології [1].

Системний підхід орієнтує на виокремлення в педагогічні системі, особистості й соціальні групі насамперед інтегрованих інваріантних системоутворювальних зв'язків і відносин. Визначають, що в системі $€$ стійким, а що перемінним, що головним, а що другорядним [2].

У XX ст. системний підхід займає одне з провідних місць у науковому пізнанні. Це пов'язано передусім зі зміною типу наукових і практичних завдань. У цілій низці галузей науки центральне місце починають займати проблеми вивчення організації та фрункціонування складних об'єктів, здатних до саморозвитку, межі і склад яких не очевидні й вимагають спеціального дослідження в кожному окремому випадку. Дослідження таких об'єктів багаторівневих, ієрархічних, що самоорганізуються, біологічних, психологічних, соціальних, технічних вимагає розгляду цих об'єктів як систем [1].
Система в педагогіці представляє собою взаємодію різних взаємозв'язаних структурних компонентів, які об'єднані однією освітньою метою розвитку індивідуальності й особистості. Педагогічна система підготовки бакалаврів 3 кібербезпеки може складатися з таких елементів, як мета навчання, зміст навчання, здобувачі вищої освіти, навчальні, методи, засоби і форми навчання.

Заслуговує на увагу визначення Г.М. Коджаспірової, яка визначає педагогічну систему як сукупність взаємопов'язаних засобів, методів і процесів, необхідних для створення організованого, цілеспрямованого педагогічного впливу на фрормування особистості із заданими якостями [3].

На думку профресора В.П. Беспалько, педагогічна система - це об'єднання компонентів (частин), які залишаються стійкими за певних педагогічних дій [4]. Педагогічна система підготовки бакалаврів 3 кібербезпеки може представляти собою сукупність елементів: здобувачів вищої освіти, цілі підготовки (загальні й особливі), зміст, технічні та мережеві засоби навчання.

Погоджуємось із думкою Л.В. Оршанського та В.К. Сидоренка [5], що педагогічна система підготовки бакалаврів 3 кібербезпеки в умовах освітньо-цифррового середовища - це сукупність взаємозалежних структурних і фрункціональних компонентів традиційного та мережевого навчання, взаємодія яких допомагає досягненню єдиної мети - професійної підготовки бакалаврів 3 кібербезпеки. Спираючись на досвід учених, зазначимо, що системний підхід щодо підготовки бакалаврів 3 кібербезпеки в умовах освітньоциоррового середовища бере в основу процеси створення і фрункціонування педагогічних систем у залежності від певних умов.

1. Наявність усвідомленої потреби суспільства в підготовці фрахівців з кібербезпеки. Тобто педагогічна система створюється тоді, коли є мета дати певній категорії людей вищу освіту за напрямом підготовки «кібербезпека».

2. Наявність накопиченої освітньої інфрормації, зокрема в умовах мережевого простору, що повинна стати предметом засвоєння майбутніми бакалаврами з кібербезпеки.

3. Розроблені способи досягнення мети, тобто відібрано засоби, методи й фрорми педагогічного впливу (способи педагогічної комунікації) на контингент здобувачів віщої освіти за напрямом підготовки «кібербезпека».

4. Наявність певної категорії абітурієнтів/здобувачів вищої освіти, які потребують відповідної підготовки та освітніх послуг за напрямом підготовки «кібербезпека» в умовах освітньо-цифрового середовища.

5. Наявність педагогічних працівників вищої освіти, які відповідають цілям системи і володіють певною інорормацією, засобами комунікації, мере- 


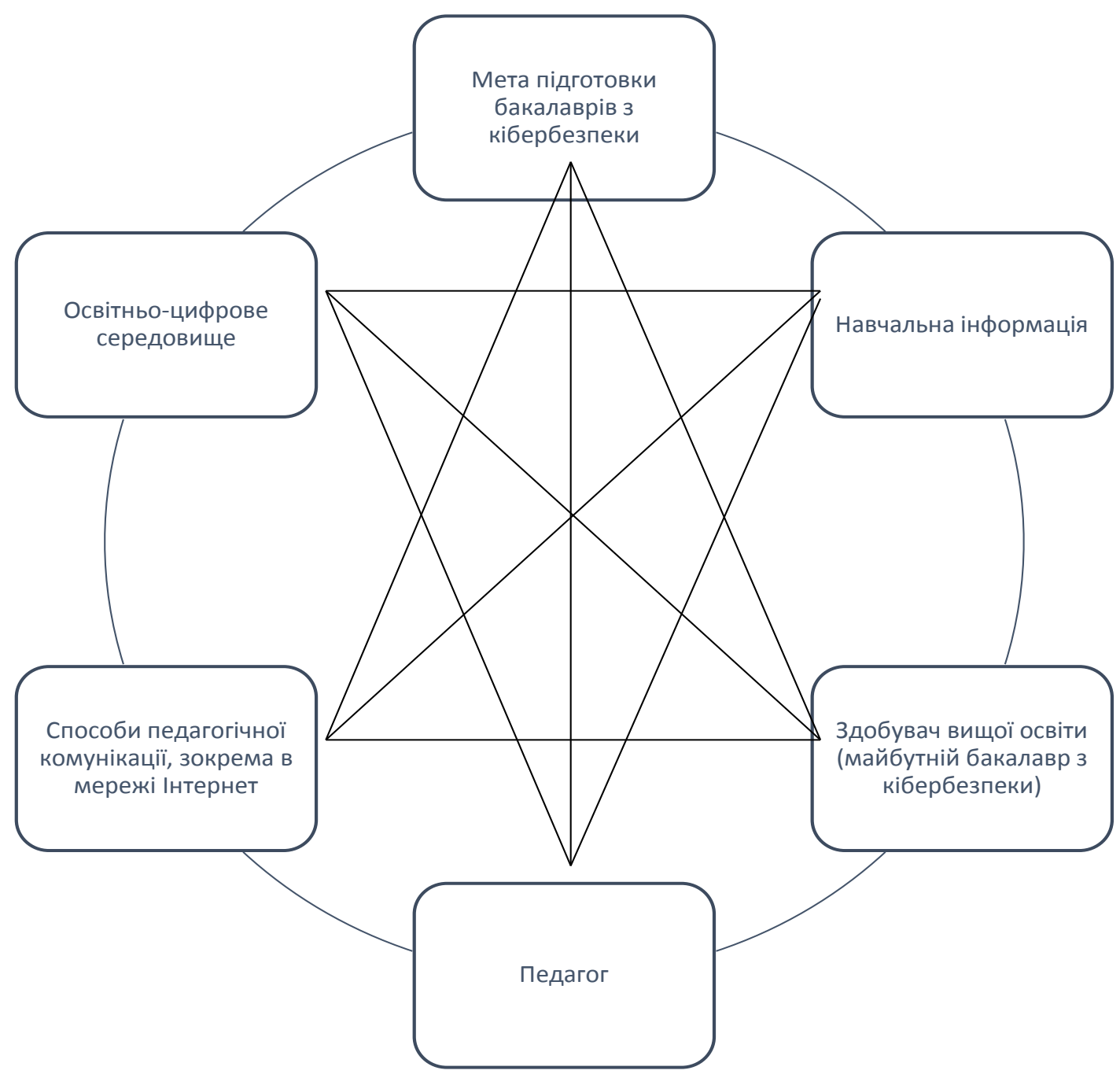

Рис. 1. Компоненти педагогічної системи підготовки бакалаврів з кібербезпеки в умовах освітньо-цифрового середовища

жевими технологіями та системами, психологічними знаннями про об'єкт педагогічного впливу.

3 позицій системного підходу окреслимо структурні компоненти педагогічної системи підготовки бакалаврів з кібербезпеки в умовах освітньо-цифрового середовища. До таких компонентів ми відносимо основні базові характеристики педагогічного процесу підготовки бакалаврів 3 кібербезпеки в умовах освітньо-циоррового середовища, сукупність та фракт наявності яких відрізняється від інших систем. 3 огляду на вищезазначені умови в педагогічній системі підготовки бакалаврів з кібербезпеки в умовах освітньо-циоррового середовища такими структурними компонентами є: мета підготовки бакалаврів з кібербезпеки, навчальна інформація, освітньо-цифррове середовище, способи педагогічної комунікації, зокрема в мережі Інтернет, здобувач вищої освіти (майбутній бакалавр із кібербезпеки) та педагог (рис. 1).

Системний підхід - це напрям фрілософрії і методології наукового пізнання, в основі якого лежить дослідження об'єктів як систем [6]. Особливість системного підходу щодо підготовки бакалаврів з кібербезпеки в умовах освітньо-цифрового середовища полягає в тому, що він орієнтований на розкриття цілісності об'єкта і забезпечуючих iї механізмів, на виявлення різноманітних типів зв'язків складного об'єкта і зведення їх в єдину теоретичну картину, зокрема в умовах глобальної мережі Інтернет.

Сутність системного підходу щодо підготовки бакалаврів 3 кібербезпеки полягає в комплексному досліджені великих і складних об'єктів (педагогічних та мережевих систем), дослідженні як єдиного цілого з узгодженим фрункціонуванням усіх елементів і частин. Згідно із системним підходом система підготовки комп'ютерних інженерів це цілісність, яка становить єдність закономірно розташованих і взаємопов'язаних частин в умовах мережевого навчання.

Висновки. Таким чином, системний підхід щодо підготовки бакалаврів 3 кібербезпеки в умовах освітньо-цифрового середовища розглядається нами як система, в якій усі компо- 
ненти взаємозв'язані й взаємозалежні. Такий підхід передбачає, що компоненти системи підготовки бакалаврів з кібербезпеки розглядаються не ізольовано, а в їх взаємозв'язку. За наших часів системний підхід можна розуміти як перспективний напрям розвитку наукового пізнання об'єктів зі складною природою. На наш погляд, застосування системного підходу сприяє значному підвищенню ефективності підготовки бакалаврів з кібербезпеки в умовах освітньо-цифрового середовища.

\section{БІБЛІОГРАФІЧНИЙ СПИСОК:}

1. Короткий курс лекцій 3 дисципліни «Теорія організації». 2015. URL: https://studme.com.ua/ 1584072011147/ekonomika/teoriya_organizatsii.htm. (дата звернення: 1606 2019).

2. Ортинський В.Л. Методологічне підґрунтя педагогіки вищої школи : навч. посіб. Київ : Центр учбової літератури, 2009.

3. Коджаспирова Г.М. Педагогика : учебник для академического бакалаврата. Москва : Издательство Юрайт, 2015.

4. Беспалько В.П. Слагаемые педагогической технологии. Москва : Педагогика, 1988.
5. Оршанський Л.В., Сидоренко В.К. Профресійна педагогіка : навчальний посібник для студентів спеціальності «Профресійне навчання». Київ, 2006.

6. Костікова І.І. Сучасні методологічні підходи профресійної підготовки вчителя засобами інформаційно-комунікаційних технологій. 2008.

7. Доценко Н.А. Моніторингова система як інструмент інорормаційно-освітнього середовища в La sciente et la technologie a I ere de la societe a I ere de la societe del information. Бордо, 2019.

8. Кашина Г.С. Система науково-природничої підготовки вчителів технологій у післядипломній освіті. Науковий часопис Національного педагогічного університету імені М.П. Драгоманова. Серія 5. Педагогічні науки: реалії та перспективи. 2018. № 63. C. 69-73.

9. Жижко Т.А. Педагогічна система як один із чинників впровадження ідеї інтенсифрікації у професійній підготовці майбутніх фрахівців. Науковий часопис НПУ імені М.П. Драгоманова. Серія 11. Соціологія. Соціальна робота. Соціальна педагогіка. Управління. № 3. С. 144-151.

10. Руснак І. Система неперервності освіти України як чинник соціальної інтеграції емігрантів у країнах Північної Америки. Гірська школа українських Карпат. 2013. № 10. С. 103-105. 